\title{
Mass mortality of marine birds in the Northeast Pacific caused by Akashiwo sanguinea
}

\author{
Timothy Jones ${ }^{1, *}$, Julia K. Parrish ${ }^{1}$, Andre E. Punt ${ }^{1}$, Vera L. Trainer ${ }^{2}$, \\ Raphael Kudela ${ }^{3}$, Jennifer Lang ${ }^{1}$, Mary Sue Brancato ${ }^{4}$, Anthony Odell ${ }^{5}$, \\ Barbara Hickey ${ }^{6}$
}

\author{
${ }^{1}$ School of Aquatic and Fishery Sciences, University of Washington, 1122 NE Boat Street, Seattle, WA 98105, USA \\ ${ }^{2}$ National Oceanic and Atmospheric Administration, National Marine Fisheries Service, Northwest Fisheries Science Center, \\ 2725 Montlake Blvd. E., Seattle, WA 98112 USA \\ ${ }^{3}$ Ocean Sciences Department, 1156 High Street, University of California, Santa Cruz, CA 95064, USA \\ ${ }^{4}$ NOAA, Office of National Marine Sanctuaries, National MPA Center, Silver Spring, MD 20910, USA \\ ${ }^{5}$ Olympic Natural Resources Center, University of Washington, PO Box 1628, Forks, WA 98331, USA \\ ${ }^{6}$ School of Oceanography, University of Washington, Seattle, WA 98105, USA
}

\begin{abstract}
Harmful algal blooms (HABs) are dense concentrations of phytoplankton that can have deleterious effects on marine life. We documented two of the largest marine bird mortality events ever definitively ascribed to a single $\mathrm{HAB}$, the cause of which was death resulting from plumage fouling by surfactant-like proteins produced by the dinoflagellate Akashiwo sanguinea. The two mortality events were observed along the coast of Washington State in September and October 2009, collectively representing an estimated deposition of 10500 carcasses, of which the majority were surf scoters, white-winged scoters and common murres. Each mortality event was coincident in space and time with observed bloom landfall, with each event preceded by a similar chain of environmental conditions. Prior to each event, the presence of $A$. sanguinea and upwelling-favourable conditions likely led to bloom proliferation. In both cases, this period was followed by conditions that transported the senescent bloom into the nearshore environment, whereupon subsequent wave action lysed A. sanguinea cells, creating foam that contained surfactant-like compounds. This sequence of conditions, exacerbated by the presence of aggregations of marine birds in wing moult, appear to be the necessary requirements for marine bird mortality of this scale due to foam-induced plumage fouling. This mechanism of HAB-induced mortality may become more prevalent in the California Current System given the apparent increasing occurrence of HABs and the broad environmental tolerances exhibited by A. sanguinea.
\end{abstract}

KEY WORDS: Harmful algal bloom · Dinoflagellates - Scoters · Common murres · Beached birds · Citizen science

\section{INTRODUCTION}

Harmful algal blooms (HABs) are a global problem (Anderson et al. 2012) with bloom events increasing in frequency and extent in coastal regions worldwide (Anderson et al. 2008, Heisler et al. 2008, Hallegraeff 2010). The causative algae are functionally grouped according to their negative effects on humans and wildlife, and mostly cause harm through the produc-

*Corresponding author: timothy.t.jones@gmail.com tion of toxins (Glibert et al. 2005), that are often concentrated and sequestered by shellfish, other invertebrates (Bargu et al. 2002, Durbin et al. 2002, Wekell et al. 2004) and forage fish (Lefebvre et al. 2002, Busse et al. 2006). When toxic prey are ingested, these compounds can produce respiratory, gastrointestinal, motor and/or neurological effects (Landsberg 2002, Landsberg et al. 2005), occasionally resulting in unusual or anomalous mortality events among marine

(C) The authors 2017. Open Access under Creative Commons by Attribution Licence. Use, distribution and reproduction are unrestricted. Authors and original publication must be credited. 
wildlife (Scholin et al. 2000, Shumway et al. 2003, Landsberg et al. 2009, Bargu et al. 2010, Miller et al. 2010).

Mortality events due to HABs have been recorded for many bird groups, including cormorants (Coulson et al. 1968, O'Shea et al. 1991, Fritz et al. 1992), terns (Nisbet 1983), waterfowl (Sasner et al. 1974, Forrester et al. 1977), alcids (Peery et al. 2006, ShearnBochsler et al. 2014), shearwaters (Bargu et al. 2012, Ayala et al. 2013) and pelicans (Work et al. 1993). While many of these events have been relatively small in magnitude (hundreds of fatalities recorded), several events have affected over a thousand birds, occasionally decimating small bird colonies (Coulson et al. 1968, Sasner et al. 1974, Sierra Beltrán et al. 1997). In 2007, a new HAB etiology was recognized during a marine bird mass mortality event (MME; Fey et al. 2015) in Monterey Bay, California (Jessup et al. 2009). Results from that event linked the presence of 'red tide' concentrations of the dinoflagellate Akashiwo sanguinea (=Gymnodinium splendens, G. nelsonii, G. sanguineum) to the production of powerful surfactant-like proteins that coated bird plumage and collapsed feathers, with a resultant loss of waterproofing and thermal insulation of over 700 birds. Blooms of A. sanguinea have been recorded globally in coastal areas (Trainer et al. 2010), including in the eastern Pacific (Cloern et al. 2005). Furthermore, this species has been identified as one of several species responsible for an increase in red-tide events in Central California and San Francisco Bay over recent years (Kudela et al. 2008). In August 2009, a largescale A. sanguinea bloom formed in the Northeast Pacific off the coast of Washington and Oregon (White et al. 2014) during a period of relaxed upwelling and elevated seawater temperatures, conditions typical of dinoflagellate blooms (Cloern et al. 2005). Unusually, this bloom persisted for several months, lasting into November (White et al. 2014). During this period, dead and moribund marine birds washed ashore in highly elevated numbers at 2 locations along the Washington coastline, concurrent with the observation of foam production and deposition on coastal beaches (Phillips et al. 2011).

In this paper, we quantified this mortality, estimating total carcass deposition during these events, which cumulatively represent one of the largest death tolls of marine birds ever definitively ascribed to a single HAB. To understand the cause of these mortality events, and why it affected so many individuals, we examined the environmental conditions leading to foam production, the spatio-temporal patterns of bloom landfall and the natural history of the marine birds affected. Recent reports have identified that the occurrence and magnitude of avian MMEs is increasing globally due to biotoxicity and multiple stressors, including shifting climate (Fey et al. 2015). Therefore, understanding the environmental and biological conditions conducive to HABs and within which HABs can cause MMEs is crucial to both local (e.g. setting state-level hunting limits) and regional (e.g. redefining transboundary population status) conservation and resource management (Zingone \& Enevoldsen 2000).

\section{MATERIALS AND METHODS}

\section{Data collection}

Data on the location, number and species identification of beach-cast carcasses of marine birds were collected by the Coastal Observation and Seabird Survey Team (COASST; a citizen science program at the University of Washington), supplemented by reports from personnel from the Quinault, Quileute, Hoh, and Makah Nations, the Olympic National Park, the Olympic Coast National Marine Sanctuary,

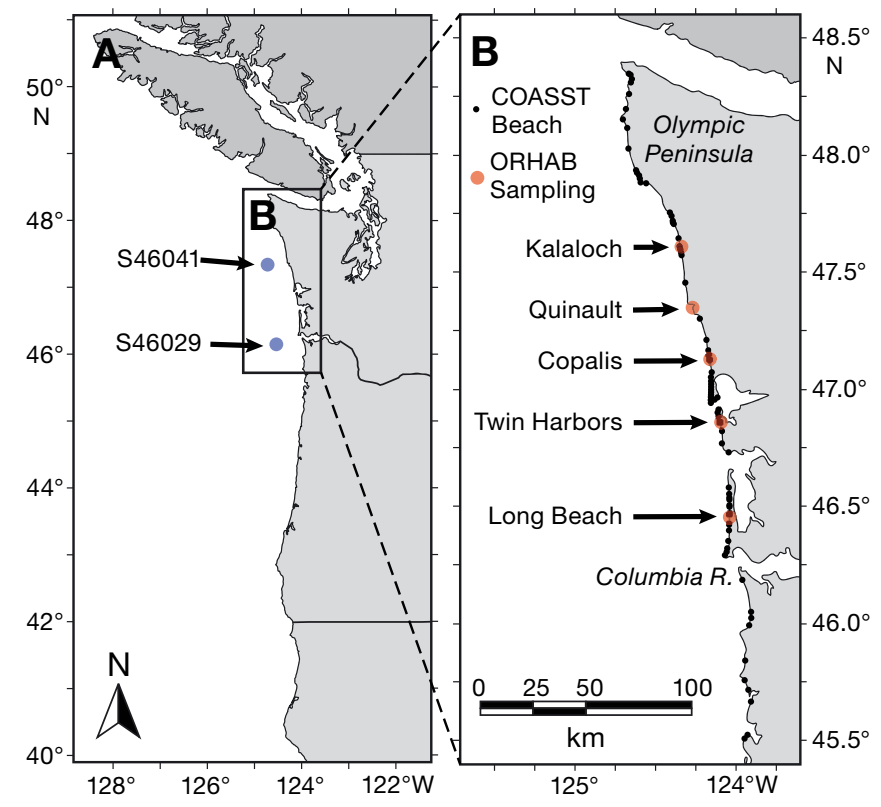

Fig. 1. (A) Study region within the northwest USA, with (B) map inset indicating the affected region within the Pacific Northwest, and the region for which deposition estimates were calculated. Blue dots: location of NOAA's National Data Buoy Center (NDBC) environmental monitoring buoys; black dots: Coastal Observation and Seabird Survey Team (COASST) survey beaches; red dots associated with place names: Olympic Region Harmful Algal Bloom (ORHAB) sampling locations 
and the Washington Department of Fish and Wildlife. Data collected by COASST from the same geographic location in non-HAB years were used to provide a baseline. In COASST, trained participants conduct standardized surveys of specific sites approximately monthly, recording all new and previously found (identified by unique tags) carcasses within a prescribed length of beach. On-site identifications are made with the help of a field guide (Hass \& Parrish 2013), and all identifications are subsequently verified by experts.

We focused our analysis on Washington outer coast beaches (Fig. 1) from August through November 2009, and on 5 groups of marine birds that comprised the majority of reported live and dead strandings (Phillips et al. 2011): (1) scoters (white-winged scoter Melanitta deglandi, surf scoter M. perspicillata and unidentified scoters Melanitta spp.), (2) common murres Uria aalge, (3) loons (Pacific loon Gavia pacifica, common loon G. immer, red-throated loon $G$. stellata and unidentified loons Gavia spp.), (4) large grebes (western grebe Aechmophorus occidentalis, Clark's grebe A. clarkii and unidentified grebes Aechmophorus spp.) and (5) cormorants (Brandt's cormorant Phalacrocorax penicillatus, pelagic cormorant P. pelagicus and unidentified cormorants Phalacrocorax spp.).

\section{Quantifying magnitude versus baseline}

Count data were used to calculate encounter rate (carcasses $\mathrm{km}^{-1}$ ). Mortality event and baseline (2001 to 2014, excluding 2009) carcass encounter rates were compared by calculating bootstrap mean and $95 \%$ confidence interval estimates for various spatiotemporal scales, and species groupings (see Section 1 of the Supplement at www.int-res.com/articles/suppl/ m579p111_supp.pdf for detailed description of the bootstrapping procedure). To examine the spatiotemporal distribution of carcass deposition, surveyspecific encounter rates for the combined counts of the 5 species groups (scoters, murres, grebes, loons and cormorants) were binned by location (six $50 \mathrm{~km}$ latitudinal bands from 45.75 to $48.5^{\circ} \mathrm{N}$ ) and month (July to December).

\section{Deposition modelling}

To quantify total carcass deposition, we constructed a model describing daily deposition rates of newly found carcasses of the target species for sur- veys carried out between 1 August 2009 and 30 November 2009, and from $45.64^{\circ} \mathrm{N}(\sim 50 \mathrm{~km}$ south of the Columbia River mouth) north to $48.34^{\circ} \mathrm{N}$ (the NW tip of the Olympic Peninsula). This incorporated 73 surveyed beaches and 387 surveys (Fig. 1). Daily carcass deposition rate was modelled assuming that the number of new carcasses on beach, $b$, on day, $d$, varied according to:

$$
N_{b, d}=S N_{b, d-1}+A_{b, d}
$$

where $S$ is the probability that an individual carcass remains from $d-1$ to $d$ (i.e. persistence) and $A_{b, d}$ is the number of birds newly deposited on beach $b$ on day $d$. Initial examination of the data revealed 2 peaks in carcass encounter rate relative to baseline. Therefore we modelled the beach- and day-specific rate of carcass deposition, $A_{b, d}$ as the summation of 2 events overlaid onto a baseline representing usual carcass deposition:

$$
A_{b, d}=\lambda_{1} f_{1}(d) \tilde{A}_{1}(b)+\lambda_{2} f_{2}(d) \tilde{A}_{2}(b)+B(b, d)
$$

where $\lambda_{i}$ determines the magnitude of event $i_{i} f_{i}(d)$ and $\tilde{A}_{i}(b)$ determine the temporal and spatial profile of each event, respectively; and $B(b, d)$ is the spatiotemporal pattern of baseline carcass deposition. The temporal functions, $f_{1-2}(d)$, determine the relative number of birds deposited on day $d$, modelled as a double logistic function in time:

$$
f_{i}(d)=\left[\left(1+\mathrm{e}^{-\left(d-\overline{d_{i s}}\right) / \beta_{i s}}\right)\left(1+\mathrm{e}^{-\left(\overline{d_{i e}}-d\right) / \beta i e}\right)\right]^{-1}
$$

where $\overline{d_{i}}$ determines the timing of the start and end of each event, $i$, and $\beta_{i}$ controls the rate of increase/ decrease in deposition with respect to time. Subscripts $s$ and $e$ indicate parameters that control the rising rate/time and falling rate/time of the function, respectively.

The value of $\tilde{A}_{i}(b)$ is the value of $R_{i}(l)$ : the rate at which birds were deposited at location, $l$, along the coast for each event, evaluated at the mid-point of the survey beach, $m_{b}$, multiplied by beach length, $L_{b}$ :

$$
\tilde{A}_{i}(b)=R_{i}\left(m_{b}\right) L_{b}
$$

The rate, $R_{i}(l)$, was similarly modelled as a double logistic function in space:

$$
R_{i}(1)=\left[\left(1+\mathrm{e}^{-\left(l-\overline{e_{i s}}\right) / \gamma_{i s}}\right)\left(1+\mathrm{e}^{-\left(\overline{e_{i e}}-l\right) / \gamma_{i e}}\right)\right]^{-1}
$$

where $\overline{e_{i}}$ determines the location and spatial extent of the events, and $\gamma_{i}$ controls the rate of increase/decrease in deposition with respect to location alongshore.

The baseline function, $B(b, d)$, was defined as 3 separate components:

$$
B_{1}(b, d)=L_{b} \lambda_{3} f_{3}(\mathrm{~d})\left[\left(1+\mathrm{e}^{-\left(m_{b}-\overline{e_{3 s}}\right) / \gamma_{3 s}}\right)\right]^{-1}
$$




$$
\begin{gathered}
B_{2}(b, d)=L_{b} \lambda_{4}\left[\left(1+\mathrm{e}^{-\left(\overline{d_{4}} e^{-d)}\right) / \beta_{4} e}\right)\right]^{-1} \\
{\left[\left(1+\mathrm{e}^{-\left(\overline{e_{4}}-m_{b}\right) / \gamma_{4} e}\right)\right]^{-1}} \\
B_{3}(b, d)=L_{b} \mu_{0}
\end{gathered}
$$

The first component (Eq. 6a) models a persistent signal (see Fig. S1 in Section 2 of the Supplement) of higher encounter rate on beaches at the northwestern tip of the Olympic Peninsula. This was modelled as a double logistic function $\left(f_{3}(d)\right)$ in time, but as a logistic function in space, as the northern boundary of this signal corresponds to the northern boundary of our data collection. The second component (Eq. 6b) models elevated deposition as a consequence of post-breeding mortality, predominantly common murres diffusing north from colonies in Oregon (Fig. S1). Only the northern edge of this signal was captured, therefore the signal was modelled as a logistic function in space and time. The third component (Eq. 6c) models a constant rate of carcass deposition $\left(\mu_{0}\right)$ to account for deposition not encompassed by the other model components.

Model parameters were estimated from the beachspecific time series of the number of newly identified carcasses, $C_{b, d}$, which was assumed to be distributed according to the negative binomial distribution, with dispersion parameter, $v_{C}$ :

$$
C_{b, d} \sim N B\left(\hat{C}_{b, d}, v_{C}\right)
$$

where $\hat{C}_{b, d}$ is the expected number of carcasses identified for the first time on beach $b$ on day $d$, given as:

$\hat{C}_{b, d}= \begin{cases}0 & d=1 \\ \phi\left[\hat{C}_{b, d^{\prime}}(1-\phi) S^{\left(d-d^{\prime}\right)}+\sum_{d^{\prime \prime}=d^{\prime}+1}^{d} A_{b, d^{\prime}} S^{\left(d-d^{\prime \prime}\right)}\right] & d \neq 1\end{cases}$

The number of carcasses on beach $b$ available to be identified for the first time on day $d$ is therefore the number of carcasses which were available to be identified during the previous survey on beach $b$ (on day $d^{\prime}$ ) but were not, less the proportion of carcasses removed from the beach (e.g. via scavenging, resuspension), plus the number of birds which were deposited on beach $b$ since the previous survey and not yet removed. The expected count of new carcasses is then the number available to be counted multiplied by the detection rate, $\phi$.

We estimated daily persistence rate, $S=0.935(95 \%$ confidence interval, CI: 0.914-0.951), and detection rate, $\phi=0.773$ (95\% CI: 0.741-0.802), from a daily survey study on selected beaches in southern Washington from 2007 to 2009. During this study, beaches were surveyed up to 10 consecutive days per month, and the unique identity of re-found birds was re- corded on all surveys. These data were reduced to individual capture histories (e.g. 1, 0, 1, 1, 0, 0) and analysed using Program MARK (White \& Burnham 1999) to determine $S$ and $\phi$. To control for seasonal variation in persistence rate, we only analysed capture histories collected during the months of September and October, the months in which the MMEs were observed in 2009. The mean estimates of $S$ and $\phi$ were included in the full deposition rate model (Eq. 8) as constants.

To inform the modelling of baseline mortality, we used previous years' data to identify priors for the spatio-temporal parameters of $B(b, d)$, (i.e. $\overline{e_{3 s}}, \overline{e_{4 e}}$, $\left.\overline{d_{4 e}}, \gamma_{3 s}, \gamma_{4 e}, \beta_{4 e}\right)$. Using data from 2003 to 2008 , we fitted the corresponding carcass count data with deposition rate modelled as $B(b, d)$ (i.e. Eq. 8 with $A_{b, d}=$ $B(b, d))$. The resulting posterior parameter estimates were used to define prior distributions of these parameters in the full deposition rate model (see Section 3 of the Supplement for more information). For all other parameters, flat priors were defined, with the exception of those controlling the start time/ locations of each event (space: $\overline{e_{1 s}}, \overline{e_{2 s}}$ i time: $\overline{d_{1 s}}, \overline{d_{2 s}}$ ) that were bounded so that label-switching (i.e. a set of parameters switching from modelling one event to another) did not occur (see Table S1 in the Supplement). Model parameters (both for the 2009-specific model and the baseline-only model) were estimated in OpenBUGS (Lunn et al. 2000) using 5 Markov chain Monte Carlo (MCMC) chains, each starting at a randomly generated set of values, with a burn-in period of 50000 iterations or until convergence was reached (determined by Brooks-Gelman-Rubin diagnostics; Brooks \& Gelman 1998). Upon convergence, a further 50000 iterations were performed to estimate model parameters see Section 3 of the Supplement. Model checks were performed based on comparisons of observed and simulated counts (see Section 4 of the Supplement).

The total number of birds deposited was determined in post-processing based on deposition rate model parameters. Total deposition, $D$, is given by the sum over $A_{b, d}$, evaluated across the entire shoreline, broken into segments denoted by $h$ :

$$
D=\sum_{h} \sum_{d} A_{h, d} I_{h}
$$

where $I_{h}$ is the proportion of each shoreline segment where bird carcasses could be deposited (i.e. excluding river mouths, inlets and coastal cliffs). To control for differences in coastline complexity, shoreline segments were interpolated to a minimum length of $1 \mathrm{~km}$. For each segment, the proportion of beach substrate, $I_{h}$, was calculated by summing the end-to-end 
distances of beach substrate relative to the combined length of beach and non-beach substrate in ArcMap v.10.4.1 (ESRI 2016). Shoreline segments were evaluated from $45.64^{\circ} \mathrm{N}, 123.94^{\circ} \mathrm{W}$ to $48.34^{\circ} \mathrm{N}, 124.69^{\circ} \mathrm{W}$, representing a summed distance of $338 \mathrm{~km}$. A distribution of total deposition estimates was obtained by sampling model parameters from converged model MCMC chains ( $\mathrm{n}=10000$; or 2000 chain $^{-1}$ ), and calculating $D$ according to Eq. (9) for each mortality event, minus baseline carcass deposition. This was subsequently processed to provide a mean and 95\% credible interval of total carcass deposition.

To identify the bird species composition of each event, the deposition model results were processed to identify the spatio-temporal extent, which was then used to assign survey- and species-specific counts to individual events. This was converted to the relative proportion of each species in each event, which was then multiplied by the estimated deposition for each event to identify species-specific estimates of carcass deposition. All post-processing of model parameters was performed in R v.3.3.2 (R Core Team 2016).

\section{Environmental conditions and bloom landfall}

Jessup et al. (2009) alluded to the conditions necessary for a marine bird mortality event caused by Akashiwo sanguinea: (1) the presence of A. sanguinea in a physiological state conducive to the release of chemical compounds characteristic of mycosporinelike amino acids, (2) transport of the cells into the nearshore surf-zone, (3) wave action to lyse the cells and churn cell contents/proteins into foam, and (4) spatio-temporal co-occurrence of foam and birds. Based on these requirements, we examined the time series of available environmental data in addition to shoreside observations of $A$. sanguinea abundance to identify the environmental precursors observed in 2009, and then tested for the presence of these conditions in other (e.g. baseline) years.

Hourly wind speed/direction and significant wave height data were obtained from buoys situated at the Columbia River Bar (Stn 46029: 47.1324 ${ }^{\circ} \mathrm{N}$, $124.518^{\circ} \mathrm{W}$ ) and Cape Elizabeth (Stn 46041: $47.350^{\circ} \mathrm{N}$, $\left.124.704^{\circ} \mathrm{W}\right)$ (NOAA/NDBC: www.ndbc.noaa.gov/). Hourly wind speed and direction data were used to calculate alongshore wind stress, $\tau_{y}$, as:

$$
\tau_{y}=\rho_{a} C_{d}|W| V
$$

where $\rho_{a}$ is the density of air $\left(1.225 \mathrm{~kg} \mathrm{~m}^{-3}\right), C_{d}$ is a dimensionless drag coefficient (taken to be $1.2 \times 10^{-3}$ ),
$|W|$ is wind speed and $V$ is the northerly component of wind velocity (Nelson 1976). Alongshore wind stress is proportional to average cross-shore transport over the surface layers via Ekman dynamics (Bakun 1975), and will be used here as a proxy for onshore-offshore transport; northward wind stress is a proxy for shoreward transport and downwelling and southward wind stress is a proxy for seaward transport and upwelling. Hourly significant wave height and $\tau_{y}$ values were then day-averaged. Hourly significant wave height was used as a proxy for the chance of cell lysis given the precursor conditions of off/onshore transport corresponding to bloom-favourable conditions followed by bloom-senescent conditions.

Observations of bloom landfall were collected by the Olympic Region Harmful Algal Bloom (ORHAB) Partnership program (Trainer \& Suddleson 2005). Seawater samples were collected on a weekly basis from the surf zone at 5 accessible beaches on the outer coast of Washington State (Fig. 1). Whole water and net tows were collected for algal species identification and enumeration following standard protocols (Trainer \& Suddleson 2005). Phytoplankton were enumerated from the coastal sampling sites using light microscopy. A. sanguinea is a naked flagellate that does not preserve well; therefore, whole water counts were performed on live samples that had been chilled $\left(4^{\circ} \mathrm{C}\right)$ to slow cell movement. A $0.1 \mathrm{ml}$ subsample was loaded into a Palmer-Maloney counting cell and individual algal cells were counted at $100 \times$ magnification.

Cell counts, day-averaged significant wave height and transport indices were plotted and aligned to identify the timing and location of bloom landfall, and the conditions that preceded and coincided with bloom landfall and seabird mortality events. Based on the observed conditions prior to the marine bird mortality events in 2009, we determined thresholds of $\tau_{\mathrm{y}}$ to proxy upwelling and onshore transport favourable conditions, and significant wave height to model hydrodynamic disturbance. These thresholds were compared to the recorded environmental conditions from 1998 to 2015 in the August to November time period, which coincides with the timing of the seabird MMEs and more frequent dinoflagellate blooms (Jester et al. 2009, Du et al. 2011).

\section{Moult model}

To explore the relationship between moulting and deposition, we used our baseline (i.e. not 2009) data to model the proportion of carcasses in moult as a function of time. These models were then used to 
statistically compare the proportion of moulting carcasses found in 2009 to what would be expected given usual (baseline) mortality processes. Moult state was assessed for all adult birds (assessed from culmen measurement: murres; feather wear: all species) where carcass condition permitted an examination of moult based on available morphometric information (wing chord measurement) and photographic evidence. Because there were insufficient numbers of loons, grebes and cormorants in the baseline dataset, these analyses were confined to scoters and common murres.

Observed moult state, $M(d)$ (moult $=1$; not-moult $=$ $0)$, was modelled as a Bernoulli random variable, with probability $p(d)$, modelled as a double-logistic function corresponding to proportional moult as a function of time, $d$ :

$$
\begin{gathered}
p(d)=\lambda\left[\left(1+\mathrm{e}^{-\left(d-\overline{d_{1}}\right) / \beta_{1}}\right)\left(1+\mathrm{e}^{-\left(\overline{d_{2}}-d\right) / \beta_{2}}\right)\right]^{-1} \\
M(d) \sim B(p(d))
\end{gathered}
$$

where $\overline{d_{1}}$ and $\overline{d_{2}}$ control moult timing, $\beta_{1}$ and $\beta_{2}$ control the rate of increase and decrease, respectively, and $\lambda$ controls the peak proportion of moulting individuals. The model described in Eqs. (11) \& (12) was fitted to the moult data using OpenBUGS (Lunn et al. 2000) as described for the deposition rate model. Using the fitted models, we generated distributions of expected values for the proportion of birds in moult based on the timing and number of birds observed. The observed proportion of moulting birds was then compared to those distributions to examine whether the moulting birds were statistically more prevalent than expected. This was performed separately for each event and species group (common murres and scoters). See Section 5 of the Supplement for a detailed description of model priors and test statistics.

\section{RESULTS}

\section{Observations and comparison with baseline}

The first reports of unusual numbers of marine birds on the beach came from hikers and rangers in the

Table 1. Carcass counts, bootstrapped average carcass encounter rates $\left(E R ;\right.$ carcasses km$\left.{ }^{-1}\right)$, and relative magnitude of the northern (10-Sep-2009 to 10-Oct-2009, 47.46 to $\left.47.95^{\circ} \mathrm{N}\right)$ and southern (19-Oct-2009 to 9-Nov-2009, 46.26 to $\left.46.66^{\circ} \mathrm{N}\right)$ events by taxonomic group. Encounter rates include the mass mortality event (MME) and baseline, with the latter calculated for the same space-time bounds across 2001 to 2014, excluding 2009. Numbers in brackets: $95 \%$ confidence intervals (CI). Bold indicates no overlap between baseline and 2009 MME $95 \%$ CIs. COMU: common murre; WWSC: white-winged scoter; SUSC: surf scoter; UkSC: scoter (unknown species); WEGR: western grebe; UkGR: grebe (unknown species, but one of Western or Clark's grebe); PALO: Pacific loon; RTLO: red-throated loon; COLO: common loon; UkLO: loon (unknown species); BRCO: Brandt's

\begin{tabular}{|c|c|c|c|c|c|c|c|c|}
\hline \multirow[t]{2}{*}{ Species } & \multicolumn{4}{|c|}{ Northern event ( 73 surveys, 16 beaches, $22.0 \mathrm{~km}$ ) } & \multicolumn{4}{|c|}{ Southern event ( 27 surveys, 14 beaches, $17.8 \mathrm{~km}$ ) } \\
\hline & Count & ER 2009 & Baseline & Magn. & Count & ER 2009 & Baseline & Magn. \\
\hline COMU & 60 & $\begin{array}{c}0.58 \\
(0.31-0.86)\end{array}$ & $\begin{array}{c}0.61 \\
(0.22-1.47)\end{array}$ & 0.9 & 234 & $\begin{array}{c}5.4 \\
(3.4-7.8)\end{array}$ & $\begin{array}{c}0.31 \\
(0.09-0.52)\end{array}$ & 17.4 \\
\hline \multicolumn{9}{|l|}{ Scoters } \\
\hline WWSC & 174 & \multirow{3}{*}{$\begin{array}{c}12.0 \\
(7.8-17.1)\end{array}$} & \multirow{3}{*}{$\begin{array}{c}0.09 \\
(0.01-0.25)\end{array}$} & \multirow{3}{*}{138.3} & 2 & \multirow{3}{*}{$\begin{array}{c}0.16 \\
(0.04-0.31)\end{array}$} & \multirow{3}{*}{$\begin{array}{c}0.05 \\
(0-0.12)\end{array}$} & \multirow{3}{*}{3.0} \\
\hline SUSC & 599 & & & & 5 & & & \\
\hline UkSC & 548 & & & & 0 & & & \\
\hline \multicolumn{9}{|l|}{ Grebes } \\
\hline WEGR & 1 & 0.01 & \multirow{2}{*}{0} & \multirow{2}{*}{ / } & 48 & \multirow{2}{*}{$\begin{array}{c}1.50 \\
(0.78-2.32)\end{array}$} & \multirow{2}{*}{$\begin{array}{c}0.16 \\
(0.06-0.28)\end{array}$} & \multirow{2}{*}{9.4} \\
\hline UkGR & 0 & $(0-0.04)$ & & & 18 & & & \\
\hline \multicolumn{9}{|l|}{ Loons } \\
\hline PALO & 1 & \multirow{4}{*}{$\begin{array}{c}0.05 \\
(0.01-0.09)\end{array}$} & \multirow{4}{*}{0} & \multirow{4}{*}{ / } & 10 & \multirow{4}{*}{$\begin{array}{c}1.04 \\
(0.37-1.82)\end{array}$} & \multirow{4}{*}{$\begin{array}{c}0.02 \\
(0-0.07)\end{array}$} & \multirow{4}{*}{49.5} \\
\hline RTLO & 3 & & & & 25 & & & \\
\hline COLO & 0 & & & & 4 & & & \\
\hline UkLO & 2 & & & & 6 & & & \\
\hline \multicolumn{9}{|c|}{ Cormorants } \\
\hline BRCO & 0 & \multirow{3}{*}{$\begin{array}{c}0.23 \\
(0.11-0.49)\end{array}$} & \multirow{3}{*}{0} & \multirow{3}{*}{ / } & 1 & \multirow{3}{*}{$\begin{array}{c}0.10 \\
(0.02-0.19)\end{array}$} & \multirow{3}{*}{$\begin{array}{c}0.01 \\
(0-0.05)\end{array}$} & \multirow{3}{*}{6.9} \\
\hline PECO & 22 & & & & 4 & & & \\
\hline $\mathrm{UkCO}$ & 1 & & & & 0 & & & \\
\hline Total & 1411 & $\begin{array}{c}12.9 \\
(8.5-18.1)\end{array}$ & $\begin{array}{c}1.0 \\
(0.5-1.9)\end{array}$ & 13.0 & 357 & $\begin{array}{c}8.2 \\
(5.5-11.8)\end{array}$ & $\begin{array}{c}0.6 \\
(0.3-0.8)\end{array}$ & 15.0 \\
\hline
\end{tabular}
cormorant; PECO: pelagic cormorant; UkCO: cormorant (unknown species) 
Olympic National Park around 10 September 2009. Within $15 \mathrm{~d}$, COASST participants and others had counted over 1000 carcasses, $94 \%$ of which were scoters, predominantly surf scoters (Table 1). This first occurrence of marine bird mortality was restricted in space along the approximately $50 \mathrm{~km}$ stretch of coastline from La Push $\left(47.91^{\circ} \mathrm{N}, 124.64^{\circ} \mathrm{W}\right)$ south to the mouth of the Queets River $\left(47.51^{\circ} \mathrm{N}, 124.36^{\circ} \mathrm{W}\right)$ (Fig. 2). Within this affected area over the $30 \mathrm{~d}$ period from 10 September to 10 October, carcass encounter rates were significantly elevated for scoters $(\sim 140 \times$ baseline). In addition, carcasses of several species of coastal diving seabirds (loons, grebes and cormorants) were observed on beaches where they had not been observed prior to, or subsequent to, 2009, including relatively high numbers $(n=22)$ of pelagic cormorants (Table 1). However, other species present in the affected area were not visibly impacted. Most notably, common murres were only observed at baseline levels (Table 1). Elsewhere along the Washington and northern Oregon coastline, carcass encounter rates were at or near baseline levels during September (Fig. 2). However, several scattered observations from Raft River $\left(47.46^{\circ} \mathrm{N}, 124.34^{\circ} \mathrm{W}\right)$ south to Pacific Beach $\left(47.20^{\circ} \mathrm{N}, 124.20^{\circ} \mathrm{W}\right)$ of high carcass encounter rates were indicative of the possible southern extent of the September event (Fig. 2).

Approximately 1 mo later (19 or 20 October 2009), marine bird carcasses were again observed in elevated numbers, this time along the Long Beach Peninsula in southern Washington (Fig. 2). From 19 October through to 9 November, a total of 357 carcasses were counted, with carcass encounter rates significantly elevated for all species groups, but primarily affecting murres (68\% of carcasses), grebes $(19 \%)$ and loons (9\%) (Table 1). Carcasses of scoters and cormorants were much less abundant, constituting only $4 \%$ of the carcass count (Table 1 ). Unlike the September event, which occurred in a remote area, the October event occurred along a populated strip of sandy beaches, from approximately North Surfside $\left(46.55^{\circ} \mathrm{N}, 125.06^{\circ} \mathrm{W}\right)$ south to the mouth of the Columbia River (Fig. 2). Efforts to rescue impaired birds at this time were immediate, and a total of 770 birds were collected and taken to rehabilitation centres. Elsewhere along the Washington and northern Oregon outer coast, carcass encounter rates were within the baseline range in October, with the excep-
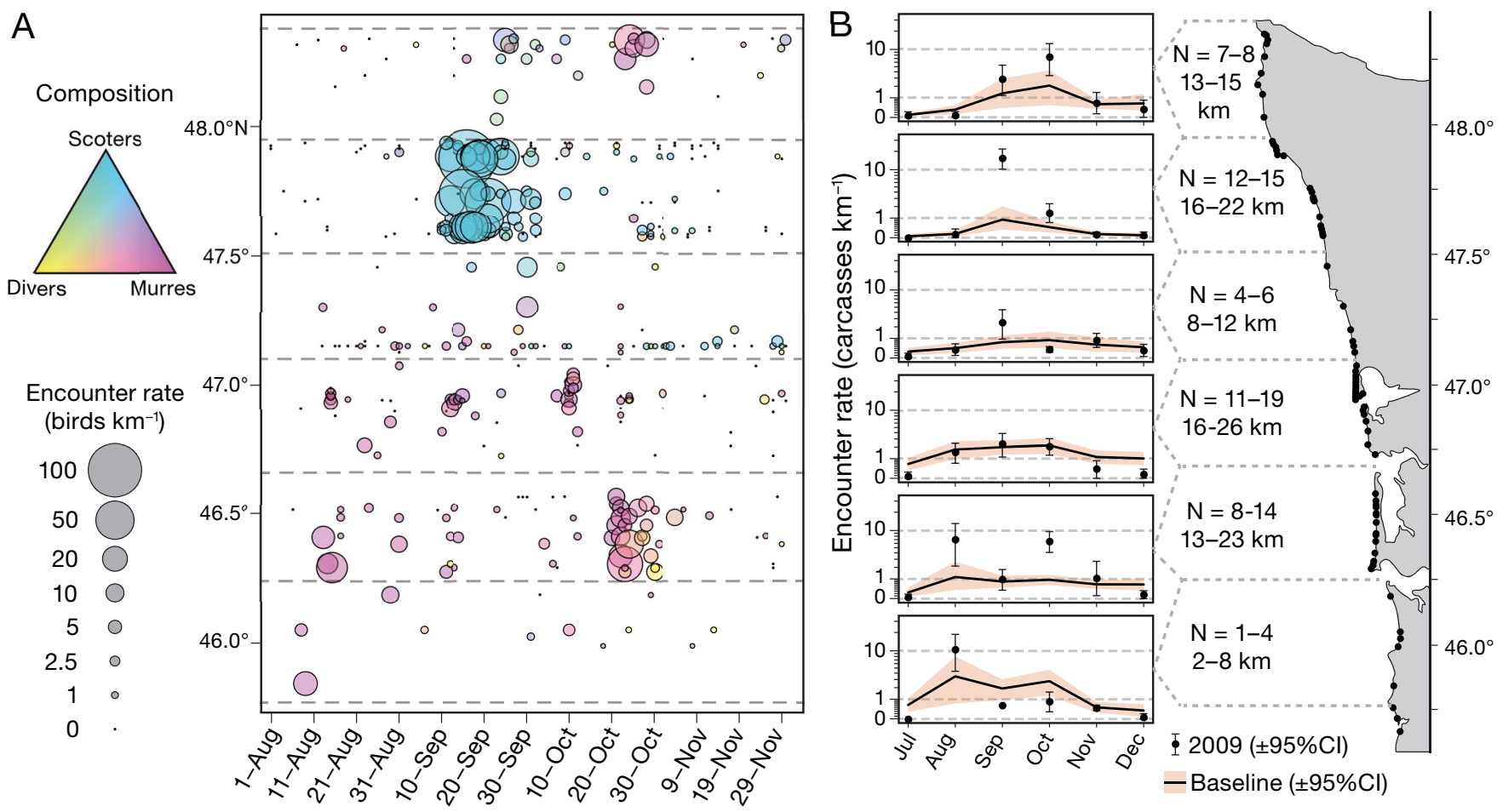

Fig. 2. (A) Observed carcass encounter rates (carcasses $\mathrm{km}^{-1}$ ) plotted as a function of date and survey latitude, with observations scaled according to recorded encounter rate, and colour coded by species composition. Divers refers to combined counts of loons, grebes and cormorants. (B) Average carcass encounter rates (log scale, $\pm 95 \%$ CI) in 2009 compared to baseline encounter rates by month within $50 \mathrm{~km}$ latitudinal bands for outer-coast Washington and northern Oregon beaches. The monthly range in the number of beaches surveyed in $2009(\mathrm{~N})$ and cumulative survey coverage (km), from July to December are presented for each latitudinal band 
tion of a small cluster of high encounter rate surveys (consisting of predominantly common murres) observed at the northwestern tip of the Olympic Peninsula in late October (Fig. 2). This signal had been observed in previous years (see Fig. S1 in Section 2 of the Supplement, and although elevated, was not significantly above baseline (Fig. 2). By November, carcass encounter rates were at baseline levels across all locations and affected species groups.

\section{Carcass deposition}

Daily deposition rate was modelled as 2 independent events in space and time representing the northern (predominantly scoter) and southern (predominantly murre) events (Fig. 3). We estimated total deposition for the northern event at 8460 (95\% credible interval: $6250-11700$ ), of which 7560 were estimated to be scoters (Table 2). This event peaked in mid-September near La Push, Washington at 34.6 carcasses $\mathrm{km}^{-1} \mathrm{~d}^{-1}$; thereafter, deposition rates declined to $<10 \times$ baseline deposition rate by 27 Sep-

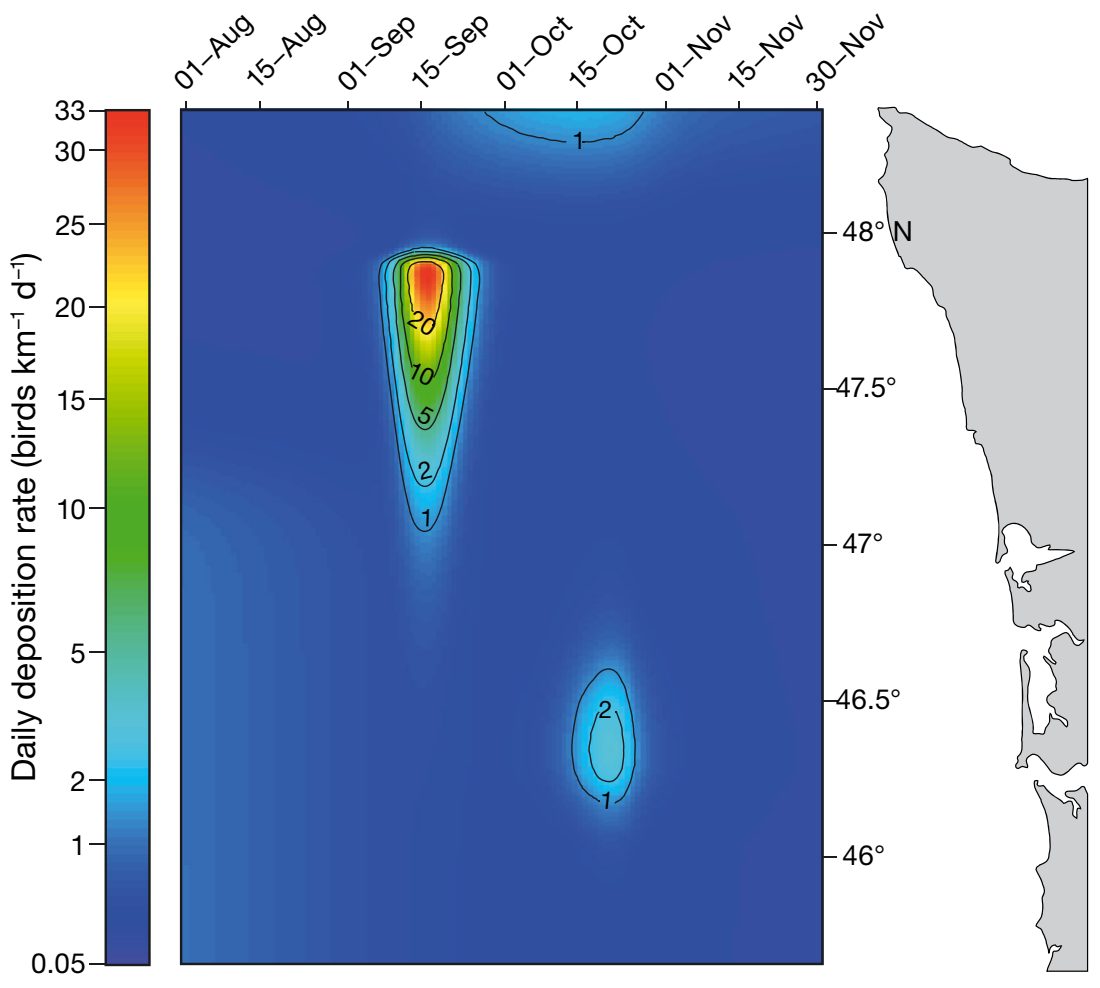

Fig. 3. Heatmap showing the mean estimated daily deposition rate (carcasses $\mathrm{km}^{-1} \mathrm{~d}^{-1}$ ) from August through November for the Washington and northern Oregon outer coastline. Plotted values are the mean across 10000 model predictions, with each prediction parameterized by values drawn at random from the Markov chain Monte Carlo (MCMC) set of converged deposition model parameter estimates tember (Table 2). The southern event was shorter in duration, less extensive and smaller in magnitude than the northern event. Restricted to the Long Beach peninsula (Fig. 3), this event peaked on 20 October at only 3.9 carcasses km $\mathrm{km}^{-1} \mathrm{~d}^{-1}$, generating an estimated 1292 carcasses (95\% CI: 714-2404), mostly common murres (Table 2). Adding the 770 birds recovered live and sent to rehabilitation facilities would increase this figure to 2062. However, assuming these birds beached in a similar pattern over space and time as the carcasses recovered during COASST surveys - that is we extrapolate counts of birds taken to rehabilitation centers according to the multiplication factor between observed carcass counts and estimated deposition for this event (multiplier $=3.62$, derived from a deposition estimate of 1292 and 357 observed carcasses) would instead add 2780 birds (3.62 times 770), approximately tripling our deposition estimate to 4000 for this event. Thus, across the 2 events, our best estimate of total deposition is 10500, when simply adding birds taken to rehabilitation centers, or 12500 , when counts of birds taken to rehabilitation centers are corrected for the difference between observed counts and estimated deposition.

\section{Moult timing and tests of 2009 moult proportions}

The baseline moult profile for scoters displayed a peak in August/early September, with proportional moult increase from essentially zero in early June, and falling back again to zero by February (Fig. 4). For common murres, the baseline moult profile had a slightly later peak (mid-September/early October) with proportional moult increasing from essentially zero in early July, also falling back to zero by February (Fig. 4). Relative to this baseline model, there were significantly more moulting scoters recovered in the 2009 Akashiwo sanguinea northern event $(67.6 \%$; $\mathrm{n}=$ $441, \mathrm{p}<1 \times 10^{-6}$ ), and marginally more common murres in moult $(53 \% ; \mathrm{n}=55$, $\mathrm{p}=0.02$ ). Scoters were only nominally present in the southern event $(n=7$, and moult state could only be determined for 5 individuals) precluding statistical comparisons; however, common murres were significantly more 
Table 2. Results of the deposition model including central tendency and range in timing, location, deposition rate and taxonomic group-specific estimates of total deposition, of the northern and southern events of the mass mortality event (MME). Event bounds were set at latitudinal and date limits where deposition rate exceeded 0.5 carcasses $\mathrm{km}^{-1} \mathrm{~d}^{-1}$, or 10 times baseline. Timing, location and daily deposition values include the estimated mean and $95 \%$ credible intervals in brackets

\begin{tabular}{|c|c|c|}
\hline & Northern & Southern \\
\hline \multicolumn{3}{|l|}{ Timing } \\
\hline Start & 7 Sep (3-10 Sep) & 13 Oct (5-19 Oct) \\
\hline Peak & 16 Sep (13-18 Sep) & 20 Oct (13-25 Oct) \\
\hline End & $27 \mathrm{Sep}$ (22 Sep-1 Oct) & 27 Oct (24 Oct-3 Nov) \\
\hline \multicolumn{3}{|l|}{ Location $\left({ }^{\circ} \mathrm{N}\right)$} \\
\hline Southern extent & $46.94(46.72-47.23)$ & $46.15(45.89-46.26)$ \\
\hline Peak & $47.88(47.82-47.89)$ & $46.35(46.14-46.60)$ \\
\hline Northern extent & $47.95(47.92-48.03)$ & $46.70(46.58-46.95)$ \\
\hline \multicolumn{3}{|l|}{ Daily deposition } \\
\hline Peak rate (carcasses $\mathrm{km}^{-1} \mathrm{~d}^{-1}$ ) & $34.6(17.2-67.2)$ & $3.9(1.1-11.9)$ \\
\hline Summed deposition & $8460(6250-11700)$ & $1292(714-2404)$ \\
\hline \multicolumn{3}{|l|}{$\%$ Species composition $\left(n / n_{\text {tot }}\right)$} \\
\hline Common murre & $7.9(119 / 1500)$ & $65.5(234 / 357)$ \\
\hline White-winged scoter & $11.9(179 / 1500)$ & $0.6(2 / 357)$ \\
\hline Surf scoter & $40.8(612 / 1500)$ & $1.4(5 / 357)$ \\
\hline Unknown scoter & $36.6(549 / 1500)$ & 0 \\
\hline Common loon & 0 & $1.1(4 / 357)$ \\
\hline Pacific loon & $0.2(3 / 1500)$ & $2.8(10 / 357)$ \\
\hline Red-throated loon & $0.3(4 / 1500)$ & $7.0(25 / 357)$ \\
\hline Unknown loon & $0.1(2 / 1500)$ & $1.7(6 / 357)$ \\
\hline Western grebe & $0.1(1 / 1500)$ & $13.4(48 / 357)$ \\
\hline Unknown grebe & $0.1(1 / 1500)$ & $5.0(18 / 357)$ \\
\hline Pelagic cormorant & $1.7(25 / 1500)$ & $1.1(4 / 357)$ \\
\hline Brandt's cormorant & $0.1(1 / 1500)$ & $0.3(1 / 357)$ \\
\hline Unknown cormorant & $0.3(4 / 1500)$ & 0 \\
\hline \multicolumn{3}{|c|}{ Estimated group-specific deposition } \\
\hline Murres & 671 & 847 \\
\hline Scoters & 7558 & 25 \\
\hline Loons & 51 & 163 \\
\hline Grebes & 11 & 239 \\
\hline Cormorants & 169 & 18 \\
\hline
\end{tabular}

likely to be in moult relative to the baseline model $\left(55 \% ; \mathrm{n}=137, \mathrm{p}=2 \times 10^{-3}\right)$.

\section{Environmental conditions and observations of A. sanguinea concentration}

The marine bird mortality events were concurrent with episodes of $A$. sanguinea bloom landfall (Fig. 5A,B). ORHAB sampling at northern stations (Kalaloch and Quinault) during the initial phase of the northern event (10 to 15 September) A. sanguinea cell concentrations ranged from $6.2 \times 10^{5}$ to $15.5 \times$ $10^{5}$ cells $1^{-1}$. Prior to and during the initial phase of the southern event (12 to 15 October), cell concentra- tions were highest at southern locations, including Long Beach $(6.3 \times$ $10^{5}$ cells $\left.^{-1}\right)$ and Twin Harbors $(1.5 \times$ $10^{5}$ cells $1^{-1}$ ). However, high A. sanguinea concentrations were recorded in locations/times with no corresponding marine bird mortality (e.g. 4 October: Twin Harbors; Fig. 5B), indicating that bloom landfall alone was not a sufficient precondition for marine bird mortality.

To explore the environmental conditions necessary to induce an MME, we constructed proxies of nutrients (upwelling or offshore transport), bloom senescence and concurrent landfall (downwelling or onshore transport) and foam creation (storm events punctuated by large and sustained waves), and compared these time series to the known timing of bloom landfall and marine bird mortality. Prior to each mortality event, surface transport conditions switched from an approximate $20 \mathrm{~d}$ period of predominantly offshore transport and upwelling-favourable conditions to a $4 \mathrm{~d}$ period of consistent onshore transport and downwellingfavourable conditions (Fig. 5D). Downwelling conditions persisted during the mortality events, and were punctuated by peaks in significant wave height (6 September: $H_{\mathrm{s}}=2.91 ; 14$ October: $H_{\mathrm{s}}=3.76$ ) indicative of storm conditions (Fig. 5C). By contrast, the early October bloom landfall at Twin Harbors occurred after much smaller transport reversal within a long period of upwelling, and no storm activity (Fig. 5B-D).

These lines of evidence support the following set and order of criteria for marine bird mortality: (1) an extended period of upwelling-favourable conditions promoting bloom proliferation, (2) a shorter period of onshore transport and downwelling-favourable conditions that moves the bloom into the surf zone and may also result in a cessation of nutrient input leading to senescence, (3) somewhat elevated wave heights allowing foam formation from lysis of senescing A. sanguinea cells without overly dissipating the senescent bloom, and (4) the spatial and temporal co-occurrence of foam formation with marine bird aggregations. 

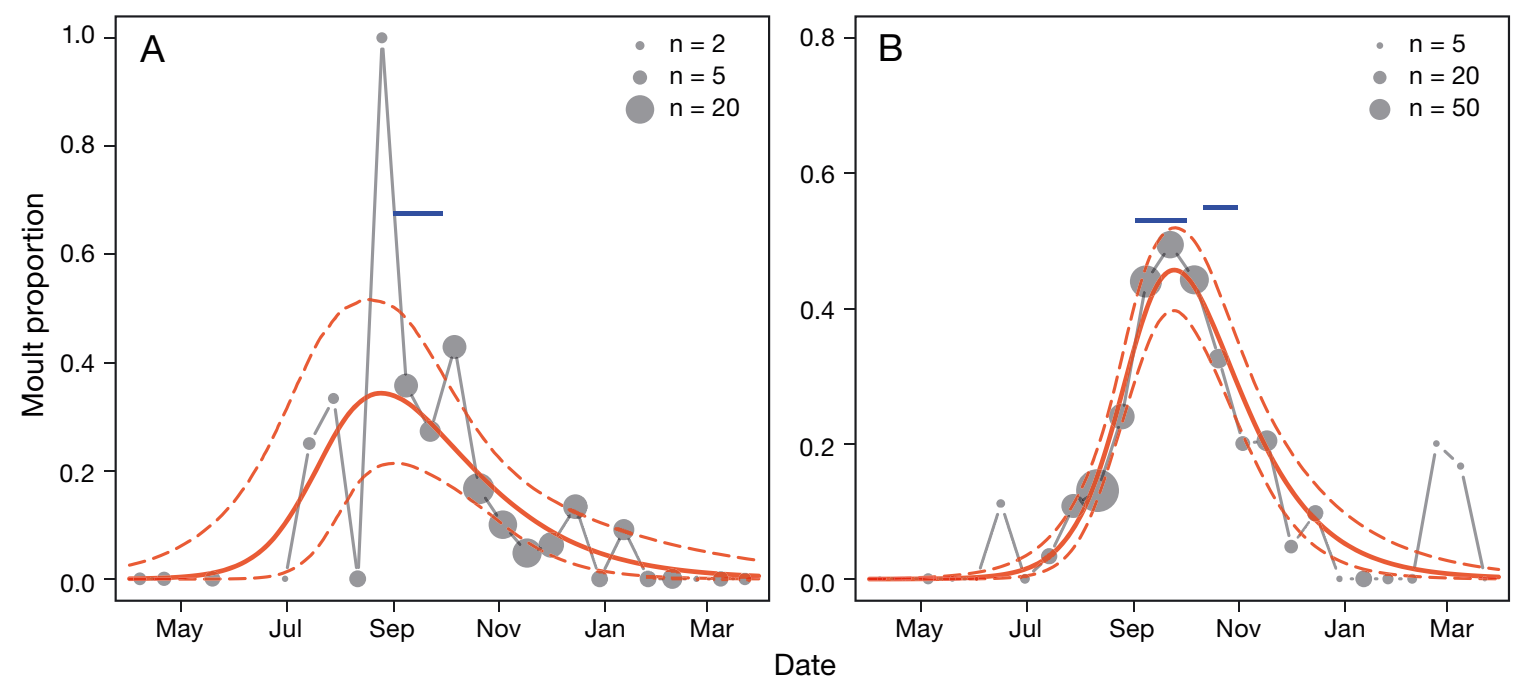

Fig. 4. Species-specific moult profiles derived from the baseline dataset: (A) scoters and (B) common murres. Grey circles: observed data averaged into $14 \mathrm{~d}$ time windows (for visualization purposes), with the number of individuals contributing toward that proportion illustrated by dot size. Red lines: fitted moult profiles (mean $\pm 95 \% \mathrm{CI}$ ). Horizontal blue bars: the observed proportion of scoters and murres, respectively, in moult during the northern (September) and southern (October) events. Scoters were omitted from the southern event due to a paucity $(n=5)$ of carcasses observed

Thresholds for criteria 1 to 3 were determined based on the conditions observed prior to each MME (Fig. 5) and applied to data from 1998 to 2015 in order to examine how frequently these conditions co-occurred in other years (Table 3). Individually, these thresholds were met on between 1 and 46 days in the August to November time period, and 2009 was not particularly anomalous relative to other years (Table 3 ). However, specifying that these conditions occur in sequenceupwelling followed by transport followed by waves narrows the number and extent of events. We allowed a $7 \mathrm{~d}$ gap between the upwelling and onshoretransport criteria (the observed gap for the northern and southern events was 1 to $4 \mathrm{~d}$ ), and a 2 d gap between transport and wave action criteria (in 2009 these criteria were met coincidentally) to account for offshore and onshore bloom persistence, respectively (alternate criteria allowances were tested, but resulted in similar conclusions; see Section 6 of the Supplement). The combined, sequential criteria were met in 6 of the 18 years examined (Table 3), suggesting that had $A$. sanguinea been a dominant component of the coastal phytoplankton community, landfall of foam would have been possible. Autumn 2009 was unique in that 2 distinct events met these combined criteria, with the September event occurring much earlier in the season than in any of the other years examined, whereas the October event occurred slightly later than when these criteria are typically met in other years (Table 3).

\section{DISCUSSION}

The extended 2009 Akashiwo sanguinea bloom off the coast of Washington State resulted in the observed death of $\sim 1800$ marine birds, impairment of an additional 770 (Phillips et al. 2011), and a best estimate of carcass/moribund bird deposition of $\sim 10500$ to 12500 individuals, making the cumulative death toll of these mortality events the largest ever definitely ascribed to a single HAB. Total mortality, including birds that died but were not deposited onshore, was certainly higher due to a combination of scavenging and sinking of carcasses at sea prior to deposition (Wiese 2003).

The majority of reported HAB-related seabird MMEs have resulted from toxin-producing algal blooms (Shumway et al. 2003), primarily those that produce saxitoxins (Alexandrium sp. and Gymnodinium sp.; Landsberg et al. 2008), domoic acid (Pseudo-nitzschia sp.; Work et al. 1993) and brevetoxins (Karenia sp.; O'Shea et al. 1991). However, large die-offs have been rare. Per event, documented mortality has been relatively low in magnitude, ranging from $<10$ individuals (Shearn-Bochsler et al. 2014) up to several thousand individuals in only a few cases (McKernan \& Scheffer 1942, Sasner et al. 1974). The 2007 MME in Monterey Bay, also a consequence of an $A$. sanguinea bloom, only resulted in $\sim 200$ carcass recoveries and $~ 500$ live impaired birds, and species-specific encounter rates that were 2 to 24 

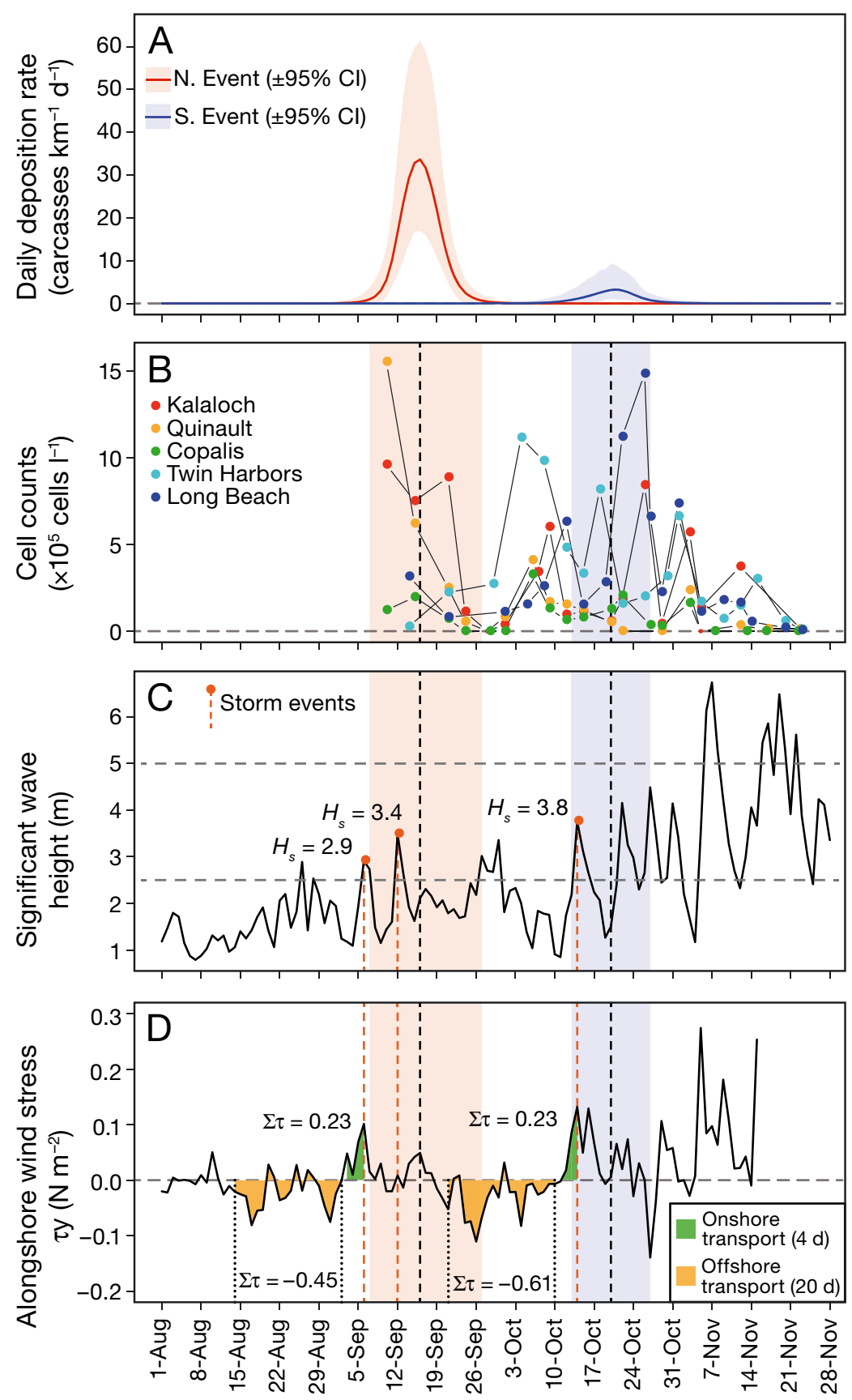

Fig. 5. (A) Time series of fitted daily deposition rates $( \pm 95 \%$ credible interval) at the peak spatial location for northern and southern events of the marine bird mass mortality event (MME). (B) Time series of Akashiwo sanguinea cell counts measured by the Olympic Region Harmful Algal Bloom (ORHAB) partnership at 5 locations along the Olympic Peninsula coastline. (C) Time series of day-averaged significant wave height $H_{\mathrm{s}}$ measured off the Washington outer coastline. Horizontal dashed lines represent significant wave height limits of 2.5 and $5 \mathrm{~m}$, and storm events preceding MME events are highlighted with red dots and vertical red dashed lines. (D) Time series of day-averaged alongshore wind stress $\left(\tau_{\mathrm{y}}\right)$ as a proxy of onshore/offshore transport calculated from wind speed/direction measured off the Washington outer coastline. Periods of onshore (downwelling) and offshore (upwelling) transport are shaded. Vertical shading: temporal limits of the northern (red) and southern (blue) MME events; dashed black lines: peak time of each event times the long-term baseline (Jessup et al. 2009) as opposed to the $\sim 140$ times baseline rate for scoters encountered along the Washington coastline during 2009. Scoters represented $79 \%$ of the estimated deposition, with an estimated $\sim 5800$ surf scoters alone washing ashore. Comparatively, this was approximately 2 times the average annual harvest of surf scoters (2717, ranging from 400 to 6487 ; Olson 2016) by waterfowl hunting along the Pacific flyway, with upper confidence bound deposition estimates 3 times the annual harvest. Although surf scoter breeding populations, recorded from breeding grounds in Alaska, declined over the 1993 to 2012 period (Bowman et al. 2015), the observed mortality in September/October 2009 represents only 1 to $2 \%$ of the surf scoter population that winters on the Pacific Coast ( 400000 ; Anderson et al. 2015), suggesting that the MME caused by A. sanguinea in 2009 likely did not have a population effect.

Although the 2009 seabird mortality events were unlikely to have had long-term population effects on those species affected, they do highlight the potential catastrophic effects that HABs may have on smaller and/or local species populations (Coulson et al. 1968, Sasner et al. 1974, Sierra-Beltrán et al. 1997). In comparison, blooms of Alexandrium sp. have caused 2 large marine bird MMEs (McKernan \& Scheffer 1942, Sasner et al. 1974), one of which occurred along the northern coast of Washington State. During that bloom, an estimated 2000 birds, primarily gulls (Laridae), scoters, murres and loons were killed (McKernan \& Scheffer 1942). Peak encounter rates were 62.5 birds km-1 (McKernan \& Scheffer 1942), or roughly half of the maximum encounter rate during the 2009 A. sanguinea MME of 120 birds $\mathrm{km}^{-1}$ (191 birds over $1.6 \mathrm{~km}$ ). Larger marine bird MMEs have been associated with red tide and/or paralytic shellfish poisoning events; however, definitive causality has been lacking. 
Table 3. Incidence of sequential environmental conditions identified as requirements for an Akashiwo sanguinea foam event along the outer coast of Washington State, evaluated from 1 August to 30 November, from 1998 to 2015. Criterion 1: upwelling conditions necessary for nutrient transport from depth; Criterion 2: downwelling inducing bloom senescence via depleted nutrients and simultaneous onshore transport of the bloom; Criterion 3: foam formation via wave action. Combined criteria allow up to a $7 \mathrm{~d}$ gap between Criteria 1 and 2 , and up to a $2 \mathrm{~d}$ gap between Criteria 2 and 3, respectively. $\mathrm{N}$ and Dates represent the number of contiguous events and the date range where all 3 criteria were met in sequence, respectively

\begin{tabular}{|c|c|c|c|c|c|c|c|c|}
\hline \multirow[t]{2}{*}{ Year } & \multicolumn{3}{|c|}{ Individual criteria (no. days) } & \multicolumn{3}{|c|}{ Combined criteria (no. days) } & \multirow[t]{2}{*}{$\mathrm{N}$} & \multirow[t]{2}{*}{ Dates } \\
\hline & $\begin{array}{l}\text { Upwelling: } \mathrm{C}_{1}(d) \\
\sum_{d-19}^{d} \tau_{y} \leq-0.4\end{array}$ & $\begin{array}{l}\text { Transport: } \mathrm{C}_{2}(d) \\
\qquad \sum_{d-3}^{d} \tau_{y} \geq 0.2\end{array}$ & $\begin{array}{l}\text { Waves: } \mathrm{C}_{3}(d) \\
5 \geq H_{s}(d) \geq 2.5\end{array}$ & $\begin{array}{c}\mathrm{C}_{1}\left(d^{\prime}\right) \& \mathrm{C}_{2}(d) \\
d-7 \leq d^{\prime} \leq d\end{array}$ & $\begin{array}{c}\mathrm{C}_{2}\left(d^{\prime}\right) \& \mathrm{C}_{3}(d) \\
d-2 \leq d^{\prime} \leq d\end{array}$ & $\mathrm{C}_{1} \& \mathrm{C}_{2} \& \mathrm{C}_{3}$ & & \\
\hline 1998 & 42 & 26 & 32 & 0 & 19 & 0 & 0 & \\
\hline 1999 & 35 & 28 & 36 & 2 & 28 & 3 & 1 & $7-9$ Oct \\
\hline 2000 & 28 & 12 & 32 & 0 & 11 & 0 & 0 & \\
\hline 2001 & 16 & 14 & 38 & 0 & 8 & 0 & 0 & \\
\hline 2002 & 53 & 16 & 20 & 0 & 13 & 0 & 0 & \\
\hline 2003 & 28 & 19 & 29 & 2 & 17 & 4 & 1 & 8-11 Oct \\
\hline 2004 & 1 & 7 & 40 & 0 & 13 & 0 & 0 & \\
\hline 2005 & 32 & 18 & 44 & 0 & 22 & 0 & 0 & \\
\hline 2006 & 57 & 24 & 37 & 0 & 21 & 0 & 0 & \\
\hline 2007 & 35 & 26 & 41 & 4 & 27 & 6 & 1 & 30 Sep to 5 Oct \\
\hline 2008 & 16 & 14 & 40 & 0 & 18 & 0 & 0 & \\
\hline 2009 & 20 & 19 & 29 & 7 & 13 & 5 & 2 & 6-7 Sep, 14-16 Oct \\
\hline 2010 & 28 & 26 & 44 & 0 & 23 & 0 & 0 & \\
\hline 2011 & 41 & 19 & 38 & 1 & 16 & 3 & 1 & 24-26 Sep \\
\hline 2012 & 38 & 32 & 30 & 5 & 21 & 5 & 1 & $14-18$ Oct \\
\hline 2013 & 33 & 8 & 22 & 2 & 6 & 0 & 0 & \\
\hline 2014 & 30 & 34 & 37 & 0 & 29 & 0 & 0 & \\
\hline 2015 & 18 & 14 & 35 & 0 & 19 & 0 & 0 & \\
\hline
\end{tabular}

Shumway et al. (2003) posited that the massive dieoff of an estimated 15000 alcids and other seabirds in the Irish Sea in 1969 (Furphy et al. 1971) and the estimated mortality of 13000 black-legged kittiwakes Rissa tridactyla in northeast England (Coulson \& Strowger 1999) may have been the result of HABs, although no evidence for (or against) phytoplankton as the causative agent was collected in either case.

In fact, the majority of confirmed and suspected HAB-induced seabird MMEs have not been well documented, and both cumulative deposition and total mortality may be much higher than reported (Shumway et al. 2003). In part, this is due to a lack of spatio-temporally comprehensive monitoring data, either at the event scale or with regard to baseline conditions. Use of standardized, rigorous citizen science monitoring efforts, including COASST and similar beachcast bird programs, can simultaneously provide needed data at a fraction of the cost of traditional science, while increasing science agency and environmental awareness of the non-scientist public (Burgess et al. 2016). Furthermore, if rigorously collected beachcast bird monitoring data were globally available, the methods applied here to estimate total carcass deposition could allow for direct comparisons of total deposition/mortality among MMEs. This would allow for better assessments of the likely relative impacts on species populations of MMEs, as the resulting estimates are not effort-dependent and allow carcass deposition to be integrated over the spatial and temporal extent of events.

Managing the effects of HABs on marine birds requires an understanding of the environmental and biotic conditions necessary for bloom proliferation, so that blooms, and the subsequent harmful impacts, can be forecasted. A. sanguinea is a cosmopolitan species (Trainer et al. 2010), previously associated with shellfish/fish die-offs and red tide events in coastal regions of Japan (Fukuyo et al. 1990), Australia and New Zealand (Hallegraeff 1992) and from the Atlantic and Pacific North American coasts (Robinson \& Brown 1983, Bockstahler \& Coats 1993, Voltolina 1993). This study, in combination with White et al. (2014), reveals the precise set, and perhaps more importantly, order of conditions necessary to produce an MME of this magnitude. The 2009 A. sanguinea bloom was unusual in that it occurred during a period of relaxed upwelling and warm temperatures, followed by a resumption of upwelling (Du et al. 2011, White et al. 2014), conditions which likely maintained and promoted further bloom proliferation. Lab cultures of $A$. sanguinea have been re- 
ported to tolerate a wide range of temperatures (10 to $30^{\circ} \mathrm{C}$ ) and salinities (5 to 40) (Matsubara et al. 2007, Boyd et al. 2013). Both broad environmental tolerances and the capacity to form resting cysts (Robinson \& Brown 1983, Voltolina 1993) may enable A. sanguinea to persist for extended periods of time.

While A. sanguinea was present in significant concentrations along coastal Washington from approximately mid-August to November (White et al. 2014), the MME was confined to 2 restricted time windows in September and October, respectively (Figs. 2 \& 3) suggesting that the bloom alone, pre-senescence, was not harmful. Following Jessup et al. (2009), we explored the 2009 data for specific environmental and natural history conditions which, when present in sequence, create ideal conditions for a MME of coastal seabirds: the presence of a senescent $A$. sanguinea bloom; onshore transport; enhanced wave action to lyse cells; co-occurrence of the foam and birds; and birds in moult (e.g. Figs. 4 \& 5). While we have no data on the ecophysiological condition of the extant blooms, the proxy time series for upwelling/ downwelling (i.e. Fig. 5D) suggests biological drawdown of nutrients during the first half of September with nutrient enhancement from upwelling (as indicated by offshore transport conditions) during late September to early October (White et al. 2014). We note that during most of early October, cells were present (White et al. 2014; Fig. 5B) and birds were present, but excessive bird mortalities were not reported. This mismatch was characterized by conditions suggestive of weak upwelling (Fig. 5D) and a lack of storm events, conditions not conducive to foam production. However, it is also clear from the water sampling data that at least portions of the bloom did reach the shore during this period (Fig. 5B) and that the bloom was also present along the coastline of Oregon (Du et al. 2011), but did not result in elevated rates of carcass deposition there. Although the Washington coastline is not considered a retentive system, the wide shelf, the relatively weak upwelling winds and the frequent presence of the plume from the Columbia River along the coast north of the river mouth during storms (Hickey \& Banas 2008) likely result in this region retaining particles, including HABs, for longer periods than, by comparison, the Oregon coast (Siedlecki et al. 2015). Thus, high concentrations of mycosporine-like amino acid compounds released from senescing cells during storm events may have been trapped as foam along the Washington shoreline. By contrast, because the Oregon coastline is relatively less retentive (Siedlecki et al. 2015), neither foam nor unusually high carcass deposition were observed along northern Oregon beaches despite the presence of the A. sanguinea bloom. Retentive systems, including Monterey Bay (Ryan et al. 2008), may be particularly prone to this specific etiology of HAB impact.

Our results also indicate that moulting birds were disproportionately affected. Moult may make individuals more susceptible in several ways: inability to escape, increased susceptibility to fouling and increased energy demand when fouled. Flight-feather moult in these species is synchronous (Bridge 2006), rendering the birds flightless for 45 to $50 \mathrm{~d}$ (Markones et al. 2010, Dickson et al. 2012). During this period, birds are particularly susceptible to locally deleterious events, such as oil spills or algal blooms (Savard et al. 2007). Pre-moult birds may also have been more susceptible to the surfactants produced by the A. sanguinea bloom, due to reduced waterproofing and insulation as a consequence of disrupted pore structure and other damage typical of pre-moult worn or damaged feathers (Stephenson 1997). The timing and species composition of the MMEs largely coincided with the timing of moult apparent in our baseline dataset (Fig. 4). Dickson et al. (2012) reported moult timing of surf and white-winged scoters to occur from late-June through late-September, overlapping the mid-September northern eventwhich overwhelmingly consisted of scoters, almost $70 \%$ of which were moulting their flight feathers. The southern event, which occurred in mid-October, involved a greater proportion of murres, grebes and loons, and relatively fewer scoters (Table 3). By midOctober the majority of scoters should have completed moulting (Dickson et al. 2012), whereas some proportion of murres (Thompson et al. 1998), loons (Barr et al. 2000) and grebes (up to 25\%; Henny et al. 1990) were likely still in an impaired state at this time due to flight-feather moult. Taken in combination, the environmental conditions necessary for foam production (e.g. Fig. 5), and the temporal overlap of moulting marine birds (e.g. Fig. 4) has occurred in approximately one-third of the last 2 decades, both before and after the $2009 \mathrm{~A}$. sanguinea bloom (Table 3). However, only in 2009 were these conditions met multiple times, starting in early September. This timing suggests that while common murres and other diving piscivores prevalent along the outer coast of Washington may be at some degree of risk annually, only in 2009 were scoters significantly at risk, as the moult timing of this species is earlier, peaking in September (Fig. 4).

Several studies have found that HABs are becoming more frequent, both globally (Hallegraeff 1993, 
Anderson et al. 2012) and along the Pacific Coast of the US (Lewitus et al. 2012). Future projections indicate a likely expansion of the spatio-temporal window for HAB development (Glibert et al. 2014), with causes variously attributed to anthropogenic sources of nutrient input (Smayda 1989, Hallegraeff 1993, Anderson et al. 2008, Heisler et al. 2008), as well as to changing climatic and oceanographic conditions, including shifts in sea surface temperature, upwelling intensity and storm-associated forcing (Bejarano et al. 2008, Moore et al. 2009, McCabe et al. 2016). Along the Iberian Peninsula, large dinoflagellate blooms - previously absent for $\sim 10 \mathrm{yr}$ - are now recurring, as are seasonal diatom/dinoflagellate oscillations comparable to those in the California system (Kudela et al. 2005, Trainer et al. 2010). The Humboldt Current System has also experienced blooms of both harmful diatom and dinoflagellate species in regions where HABs have not historically been recorded (cf. Kudela et al. 2010, Trainer et al. 2010). Within the central and southern California Current System (CCS), relative abundances of diatoms and dinoflagellates common to Monterey Bay shifted to a flagellate-dominated assemblage in 2004, prior to the 2007 A. sanguinea bloom (Jessup et al. 2009), part of a more general shift observed in the southern CCS (Venrick 2012). The unusual bloom of $A$. sanguinea in San Francisco Bay in 2004 was linked to anomalously warm conditions (Cloern et al. 2005). There is also evidence that eastern boundary current systems generally are undergoing fundamental ecological shifts and becoming more productive (Kahru et al. 2009). These conditions may lead to an increased frequency of both dinoflagellate and diatom HABs (e.g. McCabe et al. 2016), consequently increasing the potential for more frequent marine bird MMEs, particularly given the simultaneous increase in decadal wave height trends in the Pacific Northwest (Allan \& Komar 2006).

Marine bird mortality events as a likely or actual result of surfactant-producing algal blooms have rarely been reported. Suspected cases include a bloom of Coscinodiscus concinnus in the Southern German Bight in 1996 that resulted in the largest mass stranding of red-throated loons ever recorded in Europe ( 100s recorded dead; Camphuysen 1997). Other examples of plumage fouling and loss of waterproofing by an unknown green-yellow substance, similar to fouling by A. sanguinea foam, include 700 Cape gannets Morus capensis affected on Ichaboe Island, Namibia (du Toit \& Bartlett 2001) and incapacitation of 100 swift terns Sterna bergii on Robben Island, South Africa (Parsons et al. 2006).
Furthermore, the Robben Island observations cooccurred with heavy wave action and observations of meter-thick foam coming ashore (Parsons et al. 2006). However, the etiology of foam-based marine bird mortality events was not identified until the $A$. sanguinea bloom in Monterey Bay in 2007 (Jessup et al. 2009). Given the physiological flexibility of A. sanguinea (Ryan et al. 2009, Kudela et al. 2010) the rapid response of this species to favourable environmental conditions (Cloern et al. 2005) and the increase in coastal warming and climate variability, including marine heatwave events (Hobday et al. 2016, Scannell et al. 2016, McCabe et al. 2016, McKibben et al. 2017), we speculate that the frequency of foaminduced bird mortality events may continue to increase in the CCS and perhaps elsewhere.

Acknowledgements. COASST acknowledges the many hundreds of participants who have collected beachcast bird data, as well as J. Dolliver and C. Wright for their efforts coordinating the response in 2009 and H. Burgess for discussion and comments on an earlier version of the manuscript. These analyses were supported by NSF EHR/DRL awards 1114734 and 1322820, and Washington Department of Fish and Wildlife award 13-1435, to J.K.P. B.H. and R.K. were supported by the Center for Sponsored Coastal Ocean Research of the National Ocean and Atmospheric Administration (NOAA) by the ECOHAB PNWTOX program (Contribution \#892, NA09NOS4780180) and by the National Science Foundation (NSF) (PNWTOX Study, OCE-0942675). V.L.T. and B.H. were supported by the MERHAB Pacific Northwest Studies program (Contribution \#208, NA16N054780189). A.O. was supported by a surcharge to Washington State recreational shellfish licenses that provides funding to the University of Washington for monitoring by the Olympic Region Harmful Algal Bloom program (House Bill 1620). The findings and conclusions are those of the authors and do not necessarily reflect those of NSF, NOAA or the Department of Commerce.

\section{LITERATURE CITED}

Allan JC, Komar PD (2006) Climate controls on US West Coast erosion processes. J Coast Res 22:511-529

Anderson DM, Burkholder JM, Cochlan WP, Glibert PM and others (2008) Harmful algal blooms and eutrophication: examining linkages from selected coastal regions of the United States. Harmful Algae 8:39-53

* Anderson DM, Cembella AD, Hallegraeff GM (2012) Progress in understanding harmful algal blooms: paradigm shifts and new technologies for research, monitoring, and management. Annu Rev Mar Sci 4:143-176

Anderson EM, Dickson RD, Lok EK, Palm EC, Savard JPL, Bordage D, Reed A (2015) Surf scoter (Melanitta perspicillata). In: Rodewald PG (ed) The Birds of North America. Cornell Lab of Ornithology, Ithaca, NY. https:// birdsna.org/Species-Account/bna/species/sursco

Ayala L, Paz-Soldan L, Garate P (2013) A mass mortality event of sooty shearwaters (Puffinus griseus) on the cen- 
tral coast of Peru. Notornis 60:258-261

Bakun A (1975) Daily and weekly upwelling indices, west coast of North America, 1967-73. NOAA Tech. Rep 16, US Department of Commerce, Washington, DC

Bargu S, Powell CL, Coale SL, Busman M, Doucette GJ, Silver MW (2002) Krill: a potential vector for domoic acid in marine food webs. Mar Ecol Prog Ser 237:209-216

* Bargu S, Silver M, Goldstein T, Roberts K, Gulland F (2010) Complexity of domoic acid-related sea lion strandings in Monterey Bay, California: foraging patterns, climate events, and toxic blooms. Mar Ecol Prog Ser 418:213-222

Bargu S, Silver MW, Ohman MD, Benitez-Nelson CR, Garrison DL (2012) Mystery behind Hitchcock's birds. Nat Geosci 5:2-3

Barr JF, Eberl C, McIntyre JW (2000) Red-throated loon (Gavia stellata). In: Rodewald PG (ed) The birds of North America. Cornell Lab of Ornithology, Ithaca. https:// birdsna.org/Species-Account/bna/species/retloo

Bejarano AC, VanDola FM, Gulland FM, Rowles TK, Schwacke LH (2008) Production and toxicity of the marine biotoxin domoic acid and its effects on wildlife: a review. Hum Ecol Risk Assess 14:544-567

Bockstahler KR, Coats DW (1993) Grazing of the mixotrophic dinoflagellate Gymnodinium sanguineum on ciliate populations of Chesapeake Bay. Mar Biol 116:477-487

Bowman TD, Silverman ED, Gilliland SG, Leirness JB (2015) Status and trends of North American sea ducks: reinforcing the need for better monitoring. In: Savard JPL, Derksen DV, Esler D, Eadie JM (eds) Ecology and conservation of North American sea ducks. Studies in Avian Biology No. 46, CRC Press, Boca Raton, FL, p 1-28

Boyd PW, Rynearson TA, Armstrong EA, Fu F and others (2013) Marine phytoplankton temperature versus growth responses from polar to tropical waters - outcome of a scientific community-wide study. PLOS ONE 8:e63091

Bridge ES (2006) Influences of morphology and behavior on wing-moult strategies in seabirds. Mar Ornithol 34:7-19

Brooks SP, Gelman A (1998) General methods for monitoring convergence of iterative simulations. J Comput Graph Stat 7:434-455

Burgess HK, DeBey LB, Froehlich HE, Schmidt N and others (2016) The science of citizen science: exploring barriers to use as a primary research tool. Biol Conserv 208: $113-120$

Busse LB, Venrick EL, Antrobus R, Miller PE and others (2006) Domoic acid in phytoplankton and fish in San Diego, CA, USA. Harmful Algae 5:91-101

Camphuysen CJ (1997) Olievervuiling en olieslachtoffers langs de Nederlandse kust, 1969-1997: signalen van een schonere zee. Sula 11:41-156

* Cloern JE, Schraga TS, Lopez CB, Knowles N, Grover Labiosa R, Dugdale R (2005) Climate anomalies generate an exceptional dinoflagellate bloom in San Francisco Bay. Geophys Res Lett 32:L14608

Coulson JC, Strowger J (1999) The annual mortality rate of black-legged kittiwakes in NE England from 1954 to 1998 and a recent exceptionally high mortality. Waterbirds 22:3-13

Coulson JC, Potts GR, Deans IR, Fraser SM (1968) Exceptional mortality of shags and other seabirds caused by paralytic shellfish poison. Br Birds 61:381-404

* Dickson RD, Esler D, Hupp JW, Anderson EM, Evenson JR, Barrett J (2012) Phenology and duration of remigial moult in surf scoters (Melanitta perspicillata) and whitewinged scoters (Melanitta fusca) on the Pacific coast of
North America. Can J Zool 90:932-944

* Du X, Peterson W, McCulloch A, Liu G (2011) An unusual bloom of the dinoflagellate Akashiwo sanguinea off the central Oregon, USA, coast in autumn 2009. Harmful Algae 10:784-793

du Toit M, Bartlett PA (2001) 'Soaked' Cape gannets at Ichaboe Island, Namibia. Bird Numbers 10:8-9

* Durbin E, Teegarden G, Campbell R, Cembella A, Baumgartner MF, Mate BR (2002) North Atlantic right whales, Eubalaena glacialis, exposed to paralytic shellfish poisoning (PSP) toxins via a zooplankton vector, Calanus finmarchicus. Harmful Algae 1:243-251

ESRI (Environmental Systems Research Institute) (2016) ArcGIS desktop, release 10. Environmental Systems Research Institute, Redlands, CA

Fey SB, Siepielski AM, Nusslé S, Cervantes-Yoshida K and others (2015) Recent shifts in the occurrence, cause, and magnitude of animal mass mortality events. Proc Natl Acad Sci USA 112:1083-1088

F Forrester DJ, Gaskin JM, White FH, Thompson NP and others (1977) An epizootic of waterfowl associated with a red tide episode in Florida. J Wildl Dis 13:160-167

*Fritz L, Quilliam MA, Wright JL, Beale AM, Work TM (1992) An outbreak of domoic acid poisoning attributed to the pennate diatom Pseudonitzschia australis. J Phycol 28: 439-442

Fukuyo Y, Takano H, Chihara M, Matsuoka K (1990) Red tide organisms in Japan: an illustrated taxonomic guide. Uchida Rokakuho, Tokyo

Furphy JS, Hamilton FD, Merne OJ (1971) Seabird deaths in Ireland, autumn 1969. Ir Nat J 1:34-40

Glibert PM, Anderson DM, Gentien P, Granéli E, Sellner KG (2005) The global, complex phenomena of harmful algal blooms. Oceanography (Wash DC) 18:136-147

* Glibert PM, Icarus Allen J, Artioli Y, Beusen A and others (2014) Vulnerability of coastal ecosystems to changes in harmful algal bloom distribution in response to climate change: projections based on model analysis. Glob Change Biol 20:3845-3858

*Hallegraeff GM (1992) Harmful algal blooms in the Australian region. Mar Pollut Bull 25:186-190

Hallegraeff GM (1993) A review of harmful algal blooms and their apparent global increase. Phycologia 32:79-99

Hallegraeff GM (2010) Ocean climate change, phytoplankton community responses, and harmful algal blooms: a formidable predictive challenge. J Phycol 46:220-235

Hass T, Parrish JK (2013) Beached birds: a COASST field guide, 4th edn. Wavefall Press, University of Washington, Seattle, WA

* Heisler J, Glibert PM, Burkholder JM, Anderson DM and others (2008) Eutrophication and harmful algal blooms: a scientific consensus. Harmful Algae 8:3-13

Henny CJ, Blus LJ, Grove RA (1990) Western grebe, Aechmophorus occidentalis, wintering biology and contaminant accumulation in Commencement Bay, Puget Sound, Washington. Can Field Nat 104:460-472

Hickey BM, Banas NS (2008) Why is the northern end of the California Current System so productive? Oceanography (Wash DC) 21:90-107

* Hobday AJ, Alexander LV, Perkins SE, Smale DA and others (2016) A hierarchical approach to defining marine heatwaves. Prog Oceanogr 141:227-238

* Jessup DA, Miller MA, Ryan JP, Nevins HM and others (2009) Mass stranding of marine birds caused by a surfactant-producing red tide. PLOS ONE 4:e4550 
Jester R, Lefebvre K, Langlois G, Vigilant V, Baugh K, Silver MW (2009) A shift in the dominant toxin-producing algal species in central California alters phycotoxins in food webs. Harmful Algae 8:291-298

Kahru M, Kudela R, Manzano-Sarabia M, Mitchell BG (2009) Trends in primary production in the California Current detected with satellite data. J Geophys Res Oceans 114:C02004

Kudela R, Pitcher G, Probyn T, Figueiras F, Moita T, Trainer V (2005) Harmful algal blooms in coastal upwelling systems. Oceanography (Wash DC) 18:184-197

Kudela RM, Lane JQ, Cochlan WP (2008) The potential role of anthropogenically derived nitrogen in the growth of harmful algae in California, USA. Harmful Algae 8: 103-110

Kudela RM, Seeyave S, Cochlan WP (2010) The role of nutrients in regulation and promotion of harmful algal blooms in upwelling systems. Prog Oceanogr 85:122-135

Landsberg JH (2002) The effects of harmful algal blooms on aquatic organisms. Rev Fish Sci 10:113-390

Landsberg J, Van Dolah F, Doucette G (2005) Marine and estuarine harmful algal blooms: impacts on human and animal health. In: Belkin S, Colwell RR (eds) Oceans and health: pathogens in the marine environment. Springer, New York, NY, p 165-215

Landsberg JH, Vargo GA, Flewelling LJ, Wiley FE (2008). Algal biotoxins. In: Thomas NJ, Hunter DB, Atkinson ET (eds) Infectious diseases of wild birds, Blackwell Publishing, Oxford, p 431-456

Landsberg JH, Flewelling LJ, Naar J (2009) Karenia brevis red tides, brevetoxins in the food web, and impacts on natural resources: decadal advancements. Harmful Algae 8:598-607

Lefebvre K, Silver M, Coale S, Tjeerdema R (2002) Domoic acid in planktivorous fish in relation to toxic Pseudonitzschia cell densities. Mar Biol 140:625-631

* Lewitus AJ, Horner RA, Caron DA, Garcia-Mendoza E and others (2012) Harmful algal blooms along the North American west coast region: history, trends, causes, and impacts. Harmful Algae 19:133-159

Lunn DJ, Thomas A, Best N, Spiegelhalter D (2000) WinBUGS - a Bayesian modelling framework: concepts, structure, and extensibility. Stat Comput 10:325-337

Markones N, Dierschke V, Garthe S (2010) Seasonal differences in at-sea activity of seabirds underline high energetic demands during the breeding period. J Ornithol 151:329-336

Matsubara T, Nagasoe S, Yamasaki Y, Shikata T, Shimasaki Y, Oshima Y, Honjo T (2007) Effects of temperature, salinity, and irradiance on the growth of the dinoflagellate Akashiwo sanguinea. J Exp Mar Biol Ecol 342:226-230

McCabe RM, Hickey BM, Kudela RM, Lefebvre KA and others (2016) An unprecedented coastwide toxic algal bloom linked to anomalous ocean conditions. Geophys Res Lett 43:10366-10376

McKernan DL, Scheffer VB (1942) Unusual numbers of dead birds on the Washington coast. Condor 44:264-266

* McKibben M, Peterson W, Wood AM, Trainer VL, Hunter M, White AE (2017) Climatic regulation of the neurotoxin domoic acid. Proc Natl Acad Sci USA 114:239-244

Miller MA, Kudela RM, Mekebri A, Crane D and others (2010) Evidence for a novel marine harmful algal bloom: cyanotoxin (microcystin) transfer from land to sea otters. PLOS ONE 5:e12576

Moore SK, Mantua NJ, Hickey BM, Trainer VL (2009)
Recent trends in paralytic shellfish toxins in Puget Sound, relationships to climate, and capacity for prediction of toxic events. Harmful Algae 8:463-477

Nelson CS (1976) Wind stress and wind stress curl over the California Current. MSc thesis, Naval Postgraduate School, Monterey, CA

*Nisbet IC (1983) Paralytic shellfish poisoning: effects on breeding terns. Condor 85:338-345

'O'Shea TJ, Rathbun GB, Bonde RK, Buergelt CD, Odell DK (1991) An epizootic of Florida manatees associated with a dinoflagellate bloom. Mar Mamm Sci 7:165-179

Olson SM (2016) Pacific flyway data book, 2016. US Department of Interior, Fish and Wildlife Service, Division of Migratory Bird Management, Vancouver, WA

* Parsons NJ, Tjørve KM, Underhill LG, Strauss V (2006) The rehabilitation of swift terns Sterna bergii incapacitated by marine foam on Robben Island, South Africa. Ostrich 77:95-98

Peery MZ, Beissinger SR, Burkett E, Newman SH (2006) Local survival of marbled murrelets in central California: roles of oceanographic processes, sex, and radiotagging. J Wildl Manag 70:78-88

* Phillips EM, Zamon JE, Nevins HM, Gibble CM, Duerr RS, Kerr LH (2011) Summary of birds killed by a harmful algal bloom along the south Washington and north Oregon coasts during October 2009. Northwest Nat 92: $120-126$

R Core Team (2016) R: a language and environment for statistical computing. R Foundation for Statistical Computing, Vienna

Robinson MG, Brown LN (1983) A recurrent red tide in a British Columbia coastal lagoon. Can J Fish Aquat Sci 40: 2135-2143

Kyan JP, Gower JF, King SA, Bissett WP and others (2008) A coastal ocean extreme bloom incubator. Geophys Res Lett 35:L12602

Kyan JP, Fischer AM, Kudela RM, Gower JF, King SA, Marin R, Chavez FP (2009) Influences of upwelling and downwelling winds on red tide bloom dynamics in Monterey Bay, California. Cont Shelf Res 29:785-795

* Sasner J, Ikawa M, Barrett BE (1974) 'Red tide' in the southern Gulf of Maine, USA. Biol Conserv 6:76-78

* Savard JPL, Reed A, Lesage L (2007) Chronology of breeding and moult migration in surf scoters (Melanitta perspicillata). Waterbirds 30:223-229

* Scannell HA, Pershing AJ, Alexander MA, Thomas AC, Mills KE (2016) Frequency of marine heatwaves in the North Atlantic and North Pacific since 1950. Geophys Res Lett 43:2069-2076

* Scholin CA, Gulland F, Doucette GJ, Benson S and others (2000) Mortality of sea lions along the central California coast linked to a toxic diatom bloom. Nature 403:80-84

* Shearn-Bochsler V, Lance EW, Corcoran R, Piatt J, Bodenstein B, Frame E, Lawonn J (2014) Fatal paralytic shellfish poisoning in Kittlitz's murrelet (Brachyramphus brevirostris) nestlings, Alaska, USA. J Wildl Dis 50:933-937

Shumway SE, Allen SM, Boersma PD (2003) Marine birds and harmful algal blooms: Sporadic victims or underreported events? Harmful Algae 2:1-17

* Siedlecki SA, Banas NS, Davis KA, Giddings S and others (2015) Seasonal and interannual oxygen variability on the Washington and Oregon continental shelves. J Geophys Res Oceans 120:608-633

* Sierra Beltrán A, Palafox-Uribe M, Grajales-Montiel J, CruzVillacorta A, Ochoa JL (1997) Sea bird mortality at Cabo 
San Lucas, Mexico: evidence that toxic diatom blooms are spreading. Toxicon 35:447-453

Smayda TJ (1989) Primary production and the global epidemic of phytoplankton blooms in the sea: A linkage? In: Cosper EM, Bricelj VM, Carpenter EJ (eds) Novel phytoplankton blooms. Springer-Verlag, Berlin Heidelberg, p 449-483

Stephenson R (1997) Effects of oil and other surface-active organic pollutants on aquatic birds. Environ Conserv 24: 121-129

Thompson CW, Wilson ML, Melvin EF, Pierce DJ (1998) An unusual sequence of flight-feather moult in common murres and its evolutionary implications. Auk 115: 653-669

Trainer VL, Suddleson M (2005) Monitoring approaches for early warning of domoic acid events in Washington State. Oceanography (Wash DC) 18:228-237

Trainer VL, Pitcher GC, Reguera B, Smayda TJ (2010) The distribution and impacts of harmful algal bloom species in eastern boundary upwelling systems. Prog Oceanogr 85:33-52

Venrick EL (2012) Phytoplankton in the California Current system off southern California: changes in a changing environment. Prog Oceanogr 104:46-58

Editorial responsibility: Kyle Elliott,

Sainte-Anne-de-Bellevue, Québec, Canada
Voltolina D (1993) The origin of recurrent blooms of Gymnodinium sanguineum Hirasaka in a shallow coastal lagoon. J Exp Mar Biol Ecol 168:217-222

Wekell JC, Hurst J, Lefebvre KA (2004) The origin of the regulatory limits for PSP and ASP toxins in shellfish. J Shellfish Res 23:927-930

* White GC, Burnham KP (1999) Program MARK: survival estimation from populations of marked animals. Bird Study 46:S120-S139

White AE, Watkins-Brandt KS, McKibben SM, Wood AM and others (2014) Large-scale bloom of Akashiwo sanguinea in the Northern California current system in 2009. Harmful Algae 37:38-46

Wiese FK (2003) Sinking rates of dead birds: improving estimates of seabird mortality due to oiling. Mar Ornithol 31: 65-70

Work TM, Barr B, Beale AM, Fritz L, Quilliam MA, Wright JL (1993) Epidemiology of domoic acid poisoning in brown pelicans (Pelecanus occidentalis) and Brandt's cormorants (Phalacrocorax penicillatus) in California. J Zoo Wildl Med 24:54-62

Zingone A, Enevoldsen HO (2000) The diversity of harmful algal blooms: a challenge for science and management. Ocean Coast Manage 43:725-748

Submitted: April 5, 2017; Accepted: July 7, 2017

Proofs received from author(s): August 21, 2017 